\title{
KURIKULUM BUDAYA KEISLAMAN DI SEKOLAH ALAM
}

\section{CURRICULUM ISLAMIC CULTURAL IN THE NATURAL SCHOOL}

\author{
N Asiyah'1a, Yusnar'1 ${ }^{1}$ dan S Laeli ${ }^{1}$ \\ 1 Program Studi Manajemen Pendidikan Islam, Fakultas Keguruan dan Ilmu Pendidikan, \\ Universitas Djuanda Bogor, Jl. Tol Ciawi No. 1 Kotak Pos 35 Ciawi Bogor 16720 \\ a Korespondensi: Nur Asiyah, Email: nurasiyah43@yahoo.com \\ (Diterima: 21-12-2018; Ditelaah: 5-01-2019; Disetujui: 25-01-2019)
}

\begin{abstract}
The purpose of this research is to know the planning, implementation, and evaluation of the curriculum in improving the Islamic culture in the natural school cikeas. To achieve these objectives, the researcher uses a qualitative research type with case study methods that attempt to describe the situation and interpret the object as it is. Data collected through: observation, interview, and documentation. Data analysis uses: data collection, data reduction, data display, and verification. To test the validity of the data in the research, it is done by checking the data credibility through extension of participation, triangulation, and member check. The results of this study indicate that: 1) Cikeas natural school uses the curriculum of DIKNAS as a reference but for the implementation of the natural school area Cikeas has its own curriculum, which in the curriculum of cikeas schools is so complex starting from the daily habits of Greenlab activities, Outbound, Literacy, ICT , Religion Day, Outcamp, iqro and Tahfidz. The cikeas natural school has also used the 2013 curriculum but is in the 3rd and 6th grades that have not used the 2013 curriculum. 2) The implementation of the cikeas natural school culture culture using exemplary methods, and the Islamic program is not made for students only but the teachers and their parents also have activities Religion Day by itself. 3) Evaluation of the curriculum that is carried out from the learning that is the meeting of Teaching and Learning Activities at the end of the year there is a Working Meeting. For the religious evaluation of its own, the Cikeas school has a book of moral report cards, the iqro evaluation book and the recitation of prayers and the recitation of short letters. Recommendations in the form of reinforcing in the characteristics of Muslim women for school girls cikeas.
\end{abstract}

Keywords: curriculum, islamic culture.

\section{ABSTRAK}

Tujuan dari penelitian ini adalah untuk mengetahui perencanaan, pelaksanaan, dan evaluasi kurikulum dalam meningkatkan kultur keislaman di sekolah alam cikeas. Untuk mencapai tujuan tersebut, peneliti menggunakan jenis penelitian kualitatif dengan metode studi kasus yang berusaha menggambarkan keadaan dan menginterpretasikan objek sesuai dengan apa adanya. Data yang dikumpulkan melalui: observasi, wawancara, dan dokumentasi. Analisis data menggunakan: pengumpulan data, reduksi data, display data, dan verifikasi. Untuk menguji keabsahan data dalam penelitian, maka dapat dilakukan dengan mengecek data dengan cara memperpanjang keikutsertaan, triangulasi, dan member check. Hasil penelitian ini menunjukan bahwa: 1) Sekolah alam cikeas menggunakan kurikulum DIKNAS sebagai acuan namun untuk pelaksanaan dilapangan sekolah alam cikeas mempunyai kurikulum sendiri, yang mana dalam kurikulum sekolah cikeas begitu kompleks mulai dari adanya pembiasaan sehari-hari kegiatan Greenlab, Outbound, Literasi, ICT, Religion Day, Outcamp, iqro dan Tahfidz. Sekolah alam cikeas juga sudah menerapkan kurikulum 2013 tetapi tinggal 
kelas 3 dan 6 yang belum menggunakan kurikulum 2013. 2) Pelaksanaan kultur keislaman sekolah alam cikeas menggunakan metode keteladanan, dan program keislamannya pun tidak dibuat hanya untuk siswa saja melainkan guru dan orangtua nya pun mempunyai kegiatan Religion Day tersendiri. 3) Evaluasi kurikulum yang dilaksanakan mulai dari pembelajaran yaitu adanya rapat Kegiatan Beajar Mengajar dan diakhir tahun ada Rapat Kerja. Untuk evaluasi keagamaan tersendiri sekolah alam cikeas mempunyai buku rapor akhlak, buku evaluasi iqro dan hafalan do'a serta hafalan surat pendek. Rekomendasi berupa mempertegas dalam karakteristik muslimah untuk siswi sekolah alam cikeas.

Kata kunci: kurikulum, kultur keislaman.

Asiyah, N., Yusnar., \& Laeli, S. (2019). Kurikulum Budaya Keislaman di Sekolah Alam. Tadbir Muwahhid, 3(1), 83-95.

\section{PENDAHULUAN}

Untuk melihat kemajuan bangsa dapat dilihat melalui tingkat kemampuan dan kualitas pendidikan yang telah mencapai target. Pernyataan tersebut dapat menjadi pemikiran bersama bahwa negara Indonesia dalam penomena ini dapat menjadi alat ukur sebuah kemajuan pendidikan. Dalam menciptakan pendidikan yang maksimal tentunya sangat membutuhkan fasilitator pengajaran yang berkualitas sehingga proses pendidikan pun dapat menghasilkan produk yang berkualiatas pula. Berkaitan dengan dunia pendidikan yang berkualitas, disamping itu juga guru yang kompeten, manajerial sekolah yang berstandar, sehingga menjadikan siswa-siswi yang mempunyai karakter yang baik. Dalam hal ini pendidikan memiliki kedudukan dan peran strategis dalam memajukan sebuah masyarakat, bangsa, dan negara. Salah satu cara kemajuan sebuah negara pun dapat diukur dari tingkat kemajuan pendidikannya. Melalui pendidikan akanlah dipersiapkan generasi dan pemimpin yang akan mendatang. Unsur penting dalam melaksanakan pendidikan ialah kurikulum. Kurikulum merupakan kumpulan yang dapat menentukan dalam rumusan pendidikan, dikarenakan kurikulum dapat dikatakan alat yang dapat mencapai tujuan pendidikan, sekaligus menjadi acuan dalam proses pembelajaran pada semua jenis jenjang pendidikan. Sesuai dengan definisi kurikulum yang terdapat dalam UndangUndang Republik Indonesia No 20 Tahun 2003 tentang sistem pendidikan Nasional, bahwa " kurikulum merupakan formula dari sebuah perencanaan dan pengaturan mengenai tujuan, isi, dan bahan pelajaran serta metode yang dapat digunakan sebagai pedoman menyelenggarakan kegiatan pembelajaran, untuk mencapai jenjang pendidikan" (SISDIKNAS, 2013). Berdasarkan undang-undang tersebut dapat dimengerti bahwa untuk mencapai suatu pendidikan maka semua pihak terlibat dalam menggapai tujuan tersebut. Salah satu yang terpenting dalam kurikulum yaitu standar isi yang didalamnya mengatur tentang pengembangan kurikulum. Dalam mempertimbangkan suatu proses pendidikan formal tentunya pihak lembaga pendidikan harus memperhatikan kurikulum apa yang akan diaplikasikan dilapangan sesuai dengan tujuan yang ingin dikembangkan dan mengaca pada tujuan sekolah tersebut. Hal ini menyangkut dengan pengembangan kurikulum, maka mempertimbangkan suatu rumusan kurikulum harus berdasarkan pada karakteristik tujuan sekolah. Sesuai dengan arahan yang paling utama dalam 
membentuk suatu kurikulum adalah menunjukkan kurikulum yang saat ini berjalan ke tujuan pendidikan yang diharapkan. Sesuai dengan tujuan pendidikan nasional suatu bangsa menggambarkan seseorang yang baik menurut pandangan hidup negara itu. Tujuan suatu bangsa mungkin tidak akan pernah sama dengan bangsa yang lainnya, karena pandangan hidup mereka biasanya tidak akan sama. Tetapi pada hakikatnya pendidikan setiap negara biasanya sama, yaitu semua mengharapkan tercipanya insan yang baik yaitu insan yang sehat, kuat serta mempunyai keterampilan, pikirannya pintar serta berkembang dengan sempurna. Pada Konteks Agama sebagai pijakan insan mulia memiliki peranan yang sangat berpengaruh dalam perkembangan kehidupan manusia. Agama telah memposisikan manusia baik hubungan manusia dengan Khaliknya maupun berinteraksi dengan manusia. Agama selalu memberikan yang terbaik dan tidak menjerumuskan kedalam lembah hitam serta membodohi penganutnya. Untuk itu apapun dijadikan sebagai tombak untuk mempertahankan diri anak didik dalam melampaui berbagai tantangan zaman. Pada intinya tujuan penyelenggaraan pendidikan islam adalah rangka memperluas kemampuan siswa untuk lebih meningkatkan kekuatan iman dan taqwa kepada Allah SWT dalam menjalani kehidupan sehari-hari. Tentunya peran guru Agama sangat penting guna menstransfer ilmu yang mereka miliki untuk membantu anak didik berkembang lebih baik sesuai dengan nilai-nilai agama yang berlaku. Pendidikan Islam selalu lebih condong terhadap keterikatan manusai dengan Allah, manusia dengan manusia, dan manusia dengan Alam sekitar (Gunawan, 2014). Berhubungan dengan hal tersebut, terkait dengan pengembangan kurikulum terpadu Sekolah Alam maka dalam hal ini untuk menciptakan peseta didik yang menanamkan nilai ketauhidan, sangat perlu dilakukannya pengembangan kurikulum di sekolah, khususnya di sekolah Alam Cikeas Bogor dengan upaya penanaman kebiasaan melakukan kegiatan kepada peserta didik, dengan harapan membentengi mereka dari pengaruh negative lingkungan dengan diterapkannya pengembangan kurikulum kultur keislaman. Sekolah Alam Cikeas salah satu tujuan dari pada sekolah alam yaitu ingin melakukan pembiasaan dengan cara penerapan cinta melestarikan lingkungan, maka sekolah alam ini mengajarkan dengan cara menanamkan rasa cinta pada alam. Dengan cara seperti itu maka siswa/siswi akan dapat merasakan rasa cinta sejak dini dan menjadikan anak mensyukuri keagunganterbesar dari sang khaliknya, merasa memiliki dan memeliharanya sebagai amanah, sehingga akhirnya akan mengukuhkan keimanan, merasa tidak jauh dengan alam semakin mencintai Khaliknya. Dengan konsep alam ini, Sekolah Alam Cikeas memadukan konsep kurikulum pendidikan umum dengan pendidikan agama yang diaplikasikan dengan pendekatan tematik, serta memanfaatkan alam sebagai sumber belajar. Dalam proses pengembangan kurikulumnya Sekolah Alam Cikeas Bogor ini memiliki ciri khas tersendiri selain dari pada segi bangunan yang memang sesuai dengan konsep Alam akan tetapi dalam hal menarik perhatian bagi kalangan Lembaga Pendidikan yaitu menginternalisasikan kegiatan keislaman yang bukan hanya kalangan Islam, sehingga ini yang menjadi fokus penelitian yang telah menjadi acuan dalam sekolah tersebut selain dari pada itu pun peneliti memfokuskan kepada perlakuan pembudayaan keagamaan yang dilakukan 
sekolah Alam Cikeas yang meliputi pembudayaan Senyum, salam, sapa, kegiatan sholat Duha bersama, sholat berjamaah dan pembudayaan ibadah lainnya. Kreatifitas pengembangan pendidikan khususnya dalam bidang Agama Islam yang dilakukan pendidik dalam kegiatan sehari-hari di institusi sekolah tersebut membawa perubahan positif terhadap pengalaman siswa.

\section{METODE}

\section{Jenis Penelitian}

Penelitian ini menggunakan metode penelitian studi kasus, yang dapat diartikan bahwa metode ini dapat memberikan bayangan yang dapat dimisalkan sesuai dengan bentuk asalnya. Jenis penelitian yang digunakan yaitu penelitian kualitatif yang memiliki tujuan untuk mengartikan dan memperoleh secara jelas.

Penelitian kualitatif dapat dideskripsikan sebagai suatu cara yang lebih kepada mencari arti, deskriptif, desain, sifat, gejala, simbol, mengenai suatu kejadian, fokus dan memiliki banyak metode, mempunyai sifat yang natural. Adapun tujuan dari penelitian kualitatif yaitu untuk bertitik temu mengenai suatu hal yang aneh atau pertanyaan yang diaplikasikan mengikuti cara yang sistematis dengan menggunakan penelitian ini (Yusuf, 2015). Perolehan data dalam penelitian ini bukan angka-angka melainkan hanya merangkai kata yang dihasilkan dari catatan lapangan selama penelitian (Moleong L. J., 2013). Metode ini mempunyai manfaat untuk mencapai tujuan yaitu untuk memaparkan secara empirik mengenai pengembangan kurikulum terpadu di sekolah alam dan Kegiatan keislaman yang melekat atau yang menjadi khas di sekolah tersebut, maka dari penelitian ini, peneliti harus mendapatkan gambaran yang utuh dan terperinci mengenai perencanaan pengembangan kurikulum sekolah alam, pelaksanaan dan evaluasi kurikulum di Sekolah Alam Cikeas.

\section{Tempat dan waktu penelitian}

Penelitian ini dilaksanakan di Sekolah Alam Cikeas Bogor yang beralamat di Jl. Raya Cikeas Gunung Putri, kecamatan Gunung Putri Kabupaten Bogor Propinsi Jawa Barat. Subjek penelitian adalah sekolah Alam Cikeas Kabupaten Bogor. Waktu pelaksanaan penelitian di mulai dari tanggal 22 januari 2018 dan selesai tanggal 15 april 2018.

\section{Teknik Pengumpulan Data}

Pengumpulan data ialah cara yang paling prioritas dalam melakukan penelitian, karena tujuan dari sebuah hasil penelitian adalah memperoleh data. Tanpa disadari bahwa mengetahui cara mengumpulkan data, peneliti tidak akan memperoleh data yang sesuai dengan standarisasi yang sudah ditetapkan (Sugiono, 2017).

Atas dasar inilah upaya untuk memperoleh pemahaman yang mendalam mengenai permasalahan penelitian maka diperlukan beberapa teknik pengumpulan data.

\section{Observasi}

Observasi sebagai teknik untuk menjembatani antara pengumpulan data yang mempunyai khas yang mendetail bila dibandingkan dengan cara yang lain, yaitu wawancara dan kuesioner. Cara seperti ini lah sebagai jalan alternatif untuk mendapatkan informasi yang mendalam sehingga dalam pengumpulan data dengan observasi digunakan bila, penelitian berinteraksi dengan perilaku manusia secara langsung, proses kerja, gejala-gejala 
alam dan bila responden yang diamati tidak terlalu besar (Sugiono, 2017). Jenis observasi yang dipakai dalam penelitian ini adalah observasi berperanserta, penelitian terjun langsung dalam kegiatan sehari-hari serta mengamati orang yang sedang diamati atau yang digunakan sebagai sumber dan penelitian. Sambil melaksanakan pengamatan, peneliti ikut merasakan apa yang dikerjakan oleh sumber data, dan ikut merasakan pesona suka dukanya. Dengan observasi partisipan ini, maka peneliti dapat mengungkap data yang diperoleh akan menjadi lebih detail, tajam, dan sampai mengetahui pada pase yang bermakna dari setiap perilaku yang terlihat (Sugiono, 2017).

\section{Wawancara}

Wawancara difungsikan sebagai cara untuk mengetahui informasi yang akurat dan langsung secara bertatap muka maupun via alat telekomunikasi agar dalam mengumpulkan data yang peneliti harapkan agar relevan dengan perencanaan yang peneliti buat apabila peneliti ingin melaksanakan studi pendahuluan untuk menentukan atau mengetahui masalah dilapangan yang harus diteliti, dan apabila peneliti ingin mendalami serta menggali hal yang lebih banyak mengenai informasi sekolah alam maka dari responden yang lebih banyak dan mendalam serta jumlah respondennya sedikit/kecil. Teknik dalam pengumpulan data inisangat didasarkan diri pada laporan tentang diri pribadi atau self-report, atau sekira-kiranya pada hati dan pengalaman atau keyakinan pribadi (Sugiono 2017). Wawancara juga dapat dikatakan pertemuan dengan seseorang (narasumber berita) yang diperlukan untuk dimintai keterangan, data dan pendapatnya mengenai suatu hal untuk ditulis dan dimuat dalam suatu kabar (Hermawan,
2013). Peneliti dalam hal ini mengambil wawancara tidak terstruktur, karena dapat mengembangkan pertanyaan dengan lebih luas sehingga tidak terpaku pada garis besarnya saja dengan dasar agar menggali informasi lebih mendalam.

\section{Dokumentasi}

Metode dokumentasi, yaitu mencari data yang dapat di jadikan rujukan mengenai halhal yang sangat penting maka dapat diungkap melalui berupa catatan, transkip, buku, surat kabar, majalah, prasasti, notulen rapat, lengger, agenda, dan sebagainya (Arikunto, Prosedur Penelitian (Suatu Pendekatan Praktik), 2013)(Suharsimi Arikunto 2008). Dalam metode penelitian peneliti menggunakan dokumentasi foto dan dokumentasi administratif. Dokumentasi administratif dapat berupa dokumen-dokumen administratif guru dan sekolah yang berkaitan dengan penerapan kurikulum yang dianut sekolah ini, baik langsung maupun tidak langsung. Kemudian selain dari pada dokumen kurikulum saja akan tetapi kegiatan penerapan kultur keislamannya pun peneliti memakai dokumentasi foto agar membuktikan bahwa kegiatan itu berjalan dan dapat menjadikan validasi data akurat.

\section{Teknis Analisis Data}

Proses analisis data dalam melakukan penelitian ini adalah dengan menggunakan cara analisis data kualitatif. Ketiga kegiatan dalam analisis data kualitatif yang dilakukan oleh penulis pada penelitan ini adalah :

\section{Reduksi Data}

Penulis menggunakan reduksi data dengan tujuan untuk memilih data-data yang terkumpul sesuai dengan fokus penelitian kemudian data difilter sesuai dengan fokus penelitian. Data yang sudah terkumpul dari 
hasil wawancara kemudian di reduksi atau menggunakan pemilahan data dengan tujuan agar memperoleh data yang sesuai dengan memberikan gambaran yang lebih tajam sehingga memudahkan penulis untuk memilah data sewaktu ketika diperlukan. Proses pemilahan data setelah observasi dan wawancara yang didapatkan dilapangan mengenai Pengembangan kurikulum, kurikulum yang digunakan sekolah alam, konsep pengembangan kurikulum, dampak dari pengembangan kurikulum, penerapan kultur keislaman, nilai-nilai yang diterapkan dalam kultur keislaman, kegiatan apa saja yang dilakukan dalam meningkatkan kultur keislaman, dan kaitan antara pengembangan kurikulum sekolah alam dalam meningkatkan kultur keislaman. Sementara data-data yang tidak ada hubunganannya dengan permasalahan dalam penelitian agar mudah dalam penarikan kesimpulan.

\section{Penyajian Data}

Setelah data dipilah, maka cara selanjutnya adalah menguraikan data yang selama penelitian di dapat. Dalam penelitian kualitatif, penyajian data dapat dilakukan dalam bentuk deskripsi singkat, bagan, hubungan antar katogeri, dan sejenisnya. Dengan penyajian data, maka tidak akan mempersulit untuk mengerti apa yang terjadi, membuat perencanaan kerja selanjutnya berdasarkan apa yang telah dimengerti tersebut. Penyajian data dapat terwujud serangkaian informasi yang tertata rapih sehingga memberikan informasi yang akurat sehingga peneliti dapat melakukam penarikan simpulan dan pengambilan tindakan agar disajikan dengan apa yang diteliti, yaitu dengan adanya pembatasan pembahasan hanya sampai dengan permasalahan yaitu : pengembangan kurikulum sekolah alam cikeas, pelaksanaan kultur keislaman, dan bentuk evaluasi kurikulumnya.

\section{Verifikasi}

Verifikasi data atau penarikan kesimpulan data penelitian kualitatif adalah cara bagaimana dapat menemukan temuan baru yang dapat dikatakan sebelumnya yang belum pernah ada. Temuan tersebut dapat berupa deskripsi atau gambaran atau dapat dikatakan sebagai arti suatu arahan yang sebelumnya masih belum jelas atau informasi yang kurang mendetail sehingga setelah diteliti menjad lebih jelas, sehingga dapat berupa hubungan kausal atau interaktif, hipotesis dapat diartikan kemungkinan atau teori. Kesimpulan atau memperjelas data dapat didasarkan pada reduksi yang dapat dikatakan pengumpulan data dan sajian data yang merupakan jawaban atas masalah yang dimunculkan dalam penelitian. Untuk melakukan penarikan kesimpulan harus didasarkan pada semua data yang telah diperoleh selama kegiatan penelitian dan dapat menjawab dari semua permasalahan yang ada. Kesimpulan dari data-data yang sudah terkumpul untuk dijadikan bahan pembahasan yaitu kurikulum terpadu sekolah alam, pelaksanaan kultur keislaman, dan evaluasi kurikulum yang dibuat oleh sekolah alam cikeas.

Pertama, peneliti memberikan penelitian di lapangan dengan mengadakan wawancara dan observasi yang disebut tahap pengumpulan data karena data yang dikumpulkan sangat mempuni sehingga harus melalui tahapan, maka diadakan reduksi data, setelah reduksi data maka diadakan penyajian data. Apabila tiga tersebut telah di lakukan maka kita dapat menarik kesimpulan. Kegiatan tersebut dapat diulang-ulang sampai dengan data tersebut terpenuhi sehingga peneliti merasa 
cukup untuk melakukan kegiatan sesuai dengan sub fokus yang telah dibuat.

\section{HASIL DAN PEMBAHASAN}

\section{Hasil}

\section{Perencanaan Kurikulum Sekolah Alam Cikeas}

Perencanaan Kurikulum Sekolah Alam Cikeas sangatlah dipersiapkan karena dari itu, untuk perumusan kurikulumnya saja sudah menyiapkan manajerial yang baik. Maka untuk yang terlibat dalam perumusan kurikulum yaitu Divisi Litbang dan Kepala Sekolah. Penyusunan Kurikulum bukanlah hal yang sangat mudah, perlu mempertimbangkan beberapa hal bahkan sampai harus mempertimbangkan banyak hal pula. Dalam perumusan tersebut perlu mengetahui pula esensi dasar dibuatnya konsep tersebut bertujuan untuk apa, untuk siapa, dan bagaimana caranya. Menurut informasi yang peneliti dapatkan dari hasil wawancara dengan beberapa informan yang ada di Sekolah Alam Cikeas, bahwa terkait dengan perencanaan atau perumusan kurikulum Sekolah Alam Cikeas maka untuk merumuskan kurikulum tersebut perlu diadakannya Tim Khusus yang akan merumuskan kurikulum.

Sebagaimana prosedur yang sudah dibuat oleh sekolah alam cikeas, bagi yang mengarahkan desain yaitu dari pihak divisi litbang sekolah yang mana divisi litbang ini terbagi kepada dua, yang pertama khusus untuk pengembangan kurikulum dan yang kedua untuk pemberdayaan sumber daya manusia (SDM). Bagi yang membuat konsep kurikulum maka diserahkan kepada Kepala Sekolah, kemudian Kepala Sekolah dapat menyampaikan kepada guru-guru mengenai kurikulum pada saat rapat kerja (RAKER). Dalam penetapan kurikulum yang dibuat yaitu tidak semata-mata hasil keinginan perorangan, melainkan dari hasil kesepakatan beberapa pihak mulai dari guru-guru, kepala sekolah, sampai dengan divisi Litbang. Dengan demikian bahwa mengenai perumusan atau konsep perenanaan kurikulum itu, selalu melibatkan beberapa pihak agar dalam perumusan konsep tersebut benar-benar dapat diterima oleh semua warga masyarakat sekolah maupun warga masyarakat luar.

Perencanaan kurikulum yang di buat Sekolah Alam Cikeas yaitu mengacu kepada kurikulum DIKNAS atau kurikulum yang sudah dibuat oleh pemerintah. Kurikulum sekolah alam cikeas tentunya berbeda dengan kurikulum sekolah lain yang mereka punya, karena pada hakikatnya dalam sebuah perumusan kurikulum apalagi yang notabene sekolah swasta biasanya mereka selalu mengkombinasi antara kurikulum DIKNAS dan kurikulum yang menjadi khas sekolah tersebut. Sesuai dengan sudah ditetapkannya otonomi daerah maka kebebasan untuk membentuk pengembangan terhadap kurikulum atau konsep sekolah itu dikembalikan lagi kepada pemilik sekolah atau yayasan itu sendiri. Sesuai dengan kurikulum yang dibuat DIKNAS maka dari itu, sekolah alam cikeas menjadikan kurikulum DIKNAS sebagai acuan atau sandaran untuk merumuskan kurikulum, karena sekolah tidak akan pernah bisa terlepas dari peraturan pemerintah yang sudah dibuat. Untuk itu desain kurikulum yang dibuat oleh sekolah alam tentunya sangat bervariatif sehingga menjadikan pembelajaran itu menyenangkan. Dari informasi yang sudah peneliti dapatkan mengenai pengembangan kurikulum yang sudah dirancang oleh sekolah alam cikeas, sesuai dengan konsepnya yaitu bernuansa 
alam maka untuk pembelajarnnya pun mereka mengkolaborasikan dengan alam sekitar serta menumbuhkan rasa cinta terhadap alam itu sendiri. Selain dari pada itu sekolah alam cikeas mempunyai konsep yang nyatanya berbeda dengan sekolah alam pada umumnya, selain dari fasilitas yang memadai akan tetapi bobot dari pembelajarannya pun dapat dibuktikan. Hal tersebutlah yang menyatakan mengenai bentuk pengembangan kurikulum sekolah alam cikeas berbeda dengan yang lain. Sekolah alam cikeas sudah menerapkan kurikulum 2013 sebagaimana aturan pemerintah saat ini, akan tetapi belum semua kelas menerapkan kurikulum tersebut hanya ada beberapa kelas saja yang baru memakai kurikulum 2013 yang lainnya masih menggunakan KTSP 2006 (Arifin, 2013). Dengan pernyataan tersebut, bahwa menyatakan sekolah alam cikeas sama halnya dengan sekolah lain mengenai kurikulum yang digunakan akan tetapi dalam bentuk pengembangannya sekolah alam cikeas mempunyai aturan tersendiri agar menjadikan sekolah itu unggul dan berbeda.

Dalam menetapkan suatu program yang sudah dinyatakan dari hasil kesepakatan bersama, maka untuk itu sekolah alam mempunyai program khusus dalam bidang Agama. bahwa mengenai perencanaan sekolah alam cikeas, tentunya tidak sematamata memperhatikan bagian kognitifnya saja akan tetapi kepedulian terhadap Agama pun mereka lebih menanamkan apa yang seharusnya menjadi karakteristik seseorang yang beragama terlebihnya untuk Agama Islam. Konsep kurikulum yang dibuat sekolah alam cikeas terkhususnya mengenai Pendidikan Agama Islam, mengetahui tingkat kepedulian mereka terhadap Islam tidak semata-mata mereka membuat konsep tersebut akan tetapi menunjukan bahwa pendidikan agama itu sangat penting dalam kehidupan serta menyadari dengan adanya tujuan dibuatnya program tersebut. Dengan tujuan itu lah maka sekolah alam cikeas membuat program khusus mengenai keagamaan yang dinamakan dengan Religion Day. Dengan demikian tujuan yang dibuat oleh sekolah alam tak lain hanya ingin memberikan pembiasaan yang positif dan membuktikan kepeduliannya terhadap pendidikan Agama.

\section{Pelaksanaan Kultur Keislaman Sekolah Alam Cikeas}

Pelaksanaan Kultur keislaman yang dilakukan oleh sekolah alam cikeas yaitu menggunakan metode keteladanan mulai dari Pendidik dan Tenaga Kependidikan. Pelaksanaan tersebut dilakukan agar menjadi contoh yang baik, sehingga siswa dapat mengikuti apa yang menjadi pembiasaan baik yang dilakukan oleh gurugurunya. Menurut informasi yang didapatkan mengenai metode keteladanan tersebut, bahwa metode seperti itu lah yang paling tepat untuk membiasakan siswa menjalani apa yang harus mereka lakukan dalam kehidupan sehari-hari.

Pelaksanaan kultur keislaman di sekolah alam cikeas yaitu melalui pembiasaan sehari-hari, selain dari pada itu pun sekolah alam cikeas mempunyai program khusus mengenai penanaman nilai agama. Dalam kegiatan pelaksanaan kultur keislaman yang di ciptakan oleh sekolah alam cikeas tak lebih mereka mempunyai cara tersendiri untuk melakukan pembiasaan tersebut. Dari hasil wawancara yang telah peneliti lakukan bahwa untuk pembiasaannya itu mulai dari kegiatan sehari-hari seperti menanamkan senyum salam sapa, berdo'a sebelum belajar, membiasakan makan dan minum tidak sambil berdiri, berkata yang baik, tidak membuang sampah sembarangan, 
tertib dalam berprilaku, sholat duha, sholat dzuhur berjamaah, serta ada kegiatan terkhusus yaitu Religion Day. Dalam melakukan pembiasaan dari setiap kelas mereka mempunyai manajemen masingmasing sesuai dengan kebutuhan kelas tersebut. Dari program yang sudah dibuat mengenai kultur keislaman, ternyata ada beberapa sistem dalam pelaksanaan yang disesuaikan dengan tingkat kelas maupun dengan kemampuan anak. Sebagaimana informasi yang didapatkan mengenai pelaksanaan kultur keislaman, peneliti mengamati bahwa dalam pelaksanaannya memang bervariatif ada yang memang anak sudah mampu melaksanakan pembiasaan tanpa harus bimbingan lagi ada pula yang memang masih sering di ingatkan. Berdasarkan pengamatan yang peneliti lakukan, setiap melaksanakan penelitian lapangan yang berkenaan dengan dilakukannya pembiasaan kultur keislaman siswa melakukan kegiatan tersebut mulai dari awal pembelajaran hingga akhir pembelajaran. Kegiatan tersebut mulai dari membaca do'a sebelum belajar, kemudian sholat duha, sholat dzuhur berjamaah, selain dari pada itu pun siswa melakukan senyum salam sapa yang sudah di arahkan oleh wali kelas masing-masing. Dalam metode pembiasaannya pun guru-guru melakukan hal yang sama sesuai dengan apa yang dikatakan kepada siswa.

Dalam pelaksanaan kultur keislaman, sekolah alam cikeas menyediakan kegiatan Religion Day untuk guru dan orangtua murid. Untuk pelaksanaan Religion day disekolah alam cikeas sesuai dengan informasi yang didapatkan bahwa sekolah alam cikeas membuat program selain untuk siswa, guru-guru sekolah alam cikeas pun mempunyai kegiatan Religion yang dinamakan dengan Religion For Teacher, kemudian kegiatan religion untuk orangtua murid dinamakan dengan Religion For Parent. Untuk penyelenggaraan kegiatan Religion For Teacher kegiatan tersebut diakadan setiap satu bulan sekali terkadang satu bulan dua kali. Kemudian dalam pelaksanaan Religion For Parent dilakukan setiap satu bulan sekali yang bertanggal di setiap akhir bulan.

\section{Evaluasi Kurikulum Sekolah Alam Cikeas}

Evaluasi kurikulum yang dilakukan sekolah alam cikeas mulai dari kegiatan atau program yang sudah di tetapkan seperti program pembiasaan dan Religion Day. Dalam evaluasi kurikulum, sebagaimana informasi yang peneliti dapatkan mengenai evaluasi bahwa untuk evaluasi sendiri biasanya disekolah alam cikeas, untuk evaluasi dimulai dari pembelajaran yang di selanggarakan dalam rapat KBM, kemudian untuk evaluasi keseluruhan mengenai kurikulum itu dilaksanakan diakhhir tahun ajaran yaitu dalam rapat kerja (RAKER). Untuk evaluasi mengenai pembelajaran khususnya mengenai program keagamaan dan pembiasaan sehari-hari untuk bentuk evaluasinya itu sudah ditentukan oleh pihak sekolah yaitu dalam bentuk rapor atau buku capaian. Untuk kriteria penilaiannya disesuaikan dengan nilai mulia yang sekolah alam punya, maka yang mempunya rapor akhlak tersebut hanya sekolah alam cikeas saja.

Evaluasi dalam pelaksanaan kultur keislaman di sekolah alam cikeas. Untuk evaluasi baik mengenai pembelajaran atau pun kegiatan pembiasaan harian, sekolah alam cikeas membagi sesuai ajaran masingmasing. Karena disekolah alam cikeas itu merupakan sekolah umum maka untuk penilaian agama nya pun sesuai dengan agama kepercayaan pada masing-masing agamanya. Sistem penilaian yang dibuat 
oleh sekolah alam bagi yang beragam muslim, itu dibuat oleh guru spesialis agama islam, kemudian untuk penialain bagi non muslim diserahkan kepada guru agamanya sendiri. Berhubung sekolah alam cikeas tidak mempunyai guru spesialis agama maka untuk penilaiannya sekolah alam cikeas hanya menerima rekap nilai yang mereka kasih. Dengan berbagai bentuk evaluasi yang dilakukan oleh sekolah alam cikeas mengenai program yang telah dilaksanakan maka tak lain bertujuan untuk meningkatkan value sekolah alam cikeas agar dapat meningkatkan mutu sekolah tersebut.

\section{Pembahasan}

\section{Gambaran Umum Sekolah Alam Cikeas}

Sekolah alam cikeas merupakan program pendidikan Yayasan Bhakti Suratto yang mengacu pada fungsi manusia sebagai Khalifatullah Fill Ardh yang mencakup Akhlak Mulia, Logika Ilmiah, Kepemimpinan, Kewirausahaan, dan Kebangsaan. Selain itu juga memiliki konsep pendidikan yang menjadikan guru berkualitas sebagai teladan, buku sebagai gerbang ilmu, outbound sebagai sarana pembentuk kepemimpinan dan alam semesta sebagai laboratorium tanpa batas.

Pada awalnya area Sekolah Alam Cikeas (SAC) berupa ladang. Pada bulan Maret, Suratto Siswodiharjo pemilik lahan tersebut membuat sebuah aktifitas social jangka panjang. Turino Yulianto mengusulkan membangun sebuah sekolah berkonsep alam. Mereka meminta bantuan Lenda Novo, penggagas sekolah berkonsep alam. Peletakan batu pertama dan penerimaan siswa baru dilakukan di bulan Mei. Hanya empat bulan di rencanakan, SAC diresmikan pada tanggal 12 Juli 2006. Dengan bangunan yang sudah selesai yaitu dua saung kelas dan satu saung untuk ICT Room dan Perpustakaan, Sekolah Alam Cikeas mulai beroperasi untuk level Play Group, TK A, TK B, dan SD dengan 80 siswa dan 10 Fasilitator ( Pak Dicky, Pak Engkus, Bu Lina, Bu Kiki, Bu Fitri, Pak Doni, Bu Anni, Bu Hera, Pak Dwi, Bu Laksmi). Yayasan yang menaungi Sekolah Alam Cikeas yaitu Yayasan Puri Cikeas menetapkaan pimpinan sekolah yaitu; Direktur $\mathrm{Bu}$ Diah Martiningsih, Wakil Direktur, Zuwanna Corna Gumati, dan Kepala Sekolah, M Ferous. Motto sekolah alam cikeas ialah "Pengalaman adalah sekolah terbaik". Proses belajar mengajar di sekolah ala mini berlangsung dari hari senin sampai dengan jum'at masuk mulai dari jam 07.30-15.00.

Tujuan dari Sekolah Dasar Alam Cikeas berada di bawah Yayasan Bhakti Suratto yang merupakan Yayasan yang bergerak di bidang social kemasyarakatan. Sekolah Dasar Alam Cikeas didirikan oleh Yayasan Bhakti Suratto sebagai salah satu unit kegiatan social yang mengabdi pada bangsa untuk memajukan bangsa Indonesia menjadi Negara yang lebih baik di masa depan. Dengan maraknya masalah-masalah pencemaran lingkungan, isu pemanasan global, diharapkan berdirinya Sekolah Alam Cikeas akan mampu menyelesaikan permasalahan yang berhubungan dengan lingkungan hidup. Sekolah Cikeas juga didirikan juga dengan tujuan agar ma mpu berkolaborasi dengan lingkungan untuk mengembangkan alam dan budaya. Ada bermacam-macam kegiatan yang dilakukan di Sekolah Alam kegiatan sebagai strategi untuk mencapai misi Sekolah Alam Cikeas yang berupa kegiatan tahunan maupun kegiatan unggulan. Kegiatan rutin tahunan yaitu sebagai berikut : Ramadhan Camp, Gebyar Budaya Nusantara, dan Family Gathering. 
Dengan mempunyai visi “Menjadi sekolah terdepan yang mencetak generasi pemimpin berkarakter" yang mana misi tersebut ialah “1) Membangun sistem pendidikan berbasis alam dengan pembelajaran berstandar internasional sekaligus melakukan konservasi alam di lingkungan luar 2) Menyelenggarakan pendidikan yang membangun manusia yang berpengetahuan, berbadan sehat, dan berakhlak mulia. 3) Mengembangkan pendidikan berkualitas yang dapat dinikmati oleh masyarakat umum diberbagai daerah.

Sekolah alam cikeas memiliki berbagai macam ekstrakurikuler, sesuai dengan tabel 1.

Tabel 1 Kegiatan Ekstrakurikuler Sekolah Alam Cikeas

\begin{tabular}{ll}
\hline No & Nama Kegiatan Ekstrakurikuler \\
\hline 1 & Taekwondo \\
2 & Karate \\
3 & Tapak Suci \\
4 & Robotik \\
5 & Clevio Coder Camp \\
6 & Panahan \\
7 & Seni Tari \\
8 & Seni Lukis \\
9 & Iqro dan Tahfidz \\
10 & Science Club \\
11 & Fotografi \\
\hline
\end{tabular}

Selain dari pada itu ada target program dalam Religion Day sekolah alam cikeas dapat dilihat pada tabel 2 :

Tabel 2 Program Tuntas SD Alam Cikeas Boogor

Target Program

Kls 1 Tuntas Iqro Jilid I

Kls 2 Tuntas Iqro Jilid II

Kls 3 Tuntas Iqro Jilid III
Kls 4 Tuntas Iqro Jilid IV

Kls 5 Tuntas Iqro Jilid V

Kls 6 Tuntas Iqro Jilid VI/ AlQur'an

Adapun 13 nilai mulia yang selalu dilaksanakan oleh sekolah alam diantaranya ialah :

1) Takwa kepada Tuhan Yang Maha Esa

2) Jujur

3) Tauladan yang baik

4) Tekun bekerja dan cerdas

5) Bersyukur

6) Mandiri dan Inisiatif

7) IKhlas berbagi dan memberi manfaat

8) Empati

9) Peduli Lingkungan

10)Berani dan Bertanggung jawab

11)Kreatif dan Inovatif

12)Disiplin

13)Cinta Tanah Air

Dari Sekian banyak program yang ada disekolah alam cikeas Religion Day merupakan salah satu program yang unggul dalam keagamaan sehingga peneliti tertarik akan hal itu karena jarang sekali sekolah umum memiliki program khusus dalam keagamaan.

\section{KESIMPULAN DAN IMPLIKASI}

\section{Kesimpulan}

Penelitian yang telah dilaksanakan di Sekolah Alam Cikeas serta hasil analisis dapat disimpulkan bahwa :

1. Dalam perencanaan kurikulum

a. Sekolah Alam Cikeas biasanya sekolah mengadakan rapat kerja (RAKER) khusus untuk membahas mengenai perumusan kurikulum. 
b. Dalam perumusan tersebut sekolah alam cikeas mempunyai Tim Perumus, mulai dari kepala sekolah, Litbang, dan Guru-guru untuk menyepakati kurikulum yang sudah dibuat oleh Litbang dan Kepala Sekolah.

c. Konsep kurikulum yang ada di sekolah alam cikeas sangat komplek mulai dari adanya kegiatan Greenlab, Outbound, Literasi, ICT, Ecoshop, Ecocave, Outcamp, Religion Day.

d. Dalam kegiatan keagamaan diserahkan kepada Guru Spesialis Agama.

2. Pelaksanaan Kultur Keislaman

a. Sekolah alam cikeas merupakan sekolah alam yang umum namun dalam pendekatan penanaman nilai Agamanya yaitu dengan cara melakukan pembiasaan sehari-hari. Pembiasaan kegiatan sehari-hari tersebut mulai dari senyum salam sapa (3S), menjaga kebersihan, berdo'a sebelum belajar, menghafal do'a sehari-hari, menghafal surat pendek, iqro, tahfidz, sholat duha, dan sholat dzuhur berjama'ah.

b. Metode yang digunakan untuk menanamkan nilai keislaman tersebut yaitu menggunakan metode keteladanan yang mana setiap pendidik harus memberikan contoh yang terbaik sesuai dengan nilai mulia yang sudah ditetapkan oleh Sekolah Alam Cikeas.

c. Dalam penanaman keislaman disekolah alam cikeas mempunyai satu program keislaman yaitu yang dinamakan Religion Day, dimana dalam religion day ini tidak dikhususkan untuk siswa saja melainkan untuk Guru dan orangtua siswa di sekolah alam cikeas sudah menjadi program yang paten.

3. Evaluasi Kurikulum

a. Dalam pelaksanaan evaluasi di sekolah alam cikeas, dalam tahap evaluasinya mereka mulai dari diadakannya Rapat KBM, kemudian dilaksankaannya Raker.

b. Rapor Akhlak yang bertujuan untuk mengukur tingkat kemandirian anak dalam pembiasaan sehari-hari.

c. Buku prestasi hafalan surat pendek, buku prestasi hafalan do'a seharihari, dan buku evaluasi iqro.

\section{Implikasi}

Hasil penelitian yang dilaksanakan di Sekolah Alam cikeas, menunjukkan bahwa adanya pengembangan kurikulum yang signifikan baik untuk memberi pengetahuan dan pengalaman yang lebih untuk para peneliti. Oleh karena itu kiranya dapat dikembangkan penelitian yang serupa baik mengenai pengembangan kurikulum atau pun kultur keislamannya. Wujud adanya penelitian ini memberikan masukan terhadap sekolah atau lembaga pendidikan dan memberikan pengalaman berharga untuk peneliti. Maka sangat berimplikasi seandainya sekolah alam umum mempunyai manajemen keagamaan yang menyerupai sekolah islam maka dapat memberikan nilai lebih untuk lembaga tersebut sehingga pendidikan akan memiliki kualitas yang sesuai harapan masyarakat muslim.

\section{DAFTAR PUSTAKA}

Arifin, Z. (2013). Konsep dan Model Pengembangan Kurikulum. Bandung: Remaja Rosdakarya. 
Arikunto, S. (2013). Prosedur Penelitian (Suatu Pendekatan Praktik). Jakarta: Rineka Cipta.

Hermawan, W. A. (2013). Kamus Pintar Bahasa Indonesia. Jakarta: Pustaka Makmur.

Gunawan, H. (2014). Pendidikan Islam:Kajian Teoritis dan Pemikiran Tokoh. Bandung: Rosdakarya.
Moleong, L. J. (2013). Metodologi Penelitian Kualitatif. Bandung: Remaja Rosdakarya. SISDIKNAS, U.-U. (2013). Sistem Pendidikan Nasional. Bandung: Fokusmedia.

Yusuf, M. (2015). Metode Penelitian Kuantitatif, Kualitatif dan Penelitian Gabungan. Jakarta: Prenadamedia Group 